\title{
Serological diagnosis and risk factors for Coxiella burnetii in goats and sheep in a semi-arid region of Northeastern Brazil
}

\author{
Diagnóstico sorológico e fatores de risco para Coxiella burnetii em caprinos e ovinos da região \\ semiárida do nordeste do Brasil \\ Eline Almeida Rodrigues de Souza ${ }^{1}$; Elaine Monalize Serafim de Castro ${ }^{1}$; Glauber Meneses Barboza de Oliveira ${ }^{1}$; \\ Sérgio Santos Azevedo ${ }^{2}$; Rodolfo de Moraes Peixoto ${ }^{3}$; Marcelo Bahia Labruna ${ }^{4}$; Maurício Claudio Horta ${ }^{1 *}$

\begin{abstract}
${ }^{1}$ Laboratório de Doenças Parasitárias, Universidade Federal do Vale do São Francisco - UNIVASF, Petrolina, PE, Brasil
${ }^{2}$ Unidade Acadêmica de Medicina Veterinária, Universidade Federal de Campina Grande - UFCG, Patos, PB, Brasil

${ }^{3}$ Instituto Federal de Educação, Ciência e Tecnologia - IF-SERTÃO-PE, Petrolina, PE, Brasil

${ }^{4}$ Departamento de Medicina Veterinária Preventiva e Saúde Animal, Faculdade de Medicina Veterinária e Zootecnia, Universidade de Sáo Paulo - USP, São Paulo, SP, Brasil
\end{abstract}

Received June 24, 2018

Accepted October 23, 2018

\begin{abstract}
Coxiella burnetii is a zoonotic agent transmitted mainly by small ruminants. In Brazil the disease has been classified as a notifiable disease since 2013, when human cases were reported. This study aimed to identify risk factors associated with the presence of anti-Coxiella burnetii antibodies in goats and sheep in a semiarid region of Northeastern Brazil. Sera of 412 goats and 403 sheep from municipality of Petrolina, Pernambuco, were examined by the Indirect Fluorescent Antibody Test (IFAT) against antigens of $C$. burnetii. Information about management variables (independent variables) that could be associated with the presence of the microorganism (dependent variables) were obtained from the supervisor of each farm. It was determined that 2.2\% (9/412) of the goats and 2.1\% (9/403) of the sheep had antibodies reactive to C. burnetii. The presence of anti-C. burnetii antibodies was associated with the dry area of the Sequeiro (a region in the northern part of the municipality of Petrolina) $(P=0.025)$, male sheep $(P=0.020)$, and intensive goat breeding $(\mathrm{P}=0.005)$. This study therefore showed the presence of anti-C. burnetii antibodies in goat and sheep, confirming for the first time that this agent is likely circulating among goat herds in the Caatinga Biome, semi-arid of Brazil.
\end{abstract}

Keywords: Q fever, IFAT, small ruminants, zoonosis, Pernambuco.

\section{Resumo}

Coxiella burnetii é um agente zoonótico transmitido principalmente por pequenos ruminantes. No Brasil, a doença foi classificada como de notificaçáo compulsória desde 2013, quando casos humanos foram relatados. O objetivo deste estudo foi identificar os fatores de risco associados à presença de anticorpos anti-Coxiella burnetii em caprinos e ovinos em uma regiáo semiárida do Nordeste do Brasil. Este estudo envolveu um inquérito sorológico de 412 caprinos e 403 ovinos em fazendas do município de Petrolina, no estado de Pernambuco. Os soros foram examinados pela Reação de Imunofluorescência Indireta (RIFI) contra antígenos de C. burnetii. Informaçóes sobre variáveis de manejo (variáveis independentes) que poderiam estar associadas à presença do microrganismo (variáveis dependentes) foram obtidas do proprietário de cada fazenda. Foi determinado que 2,2\% (9/412) dos caprinos e 2,1\% (9/403) dos ovinos tinham anticorpos reativos a $C$. burnetii. A presença de anticorpos anti- $C$. burnetii foram associados com a área seca do Sequeiro (regiáa no norte do município de Petrolina) $(\mathrm{P}=0,025)$, ovinos machos $(\mathrm{P}=0,020)$ e criaçáo intensiva de caprinos $(\mathrm{P}=0,005)$. Este estudo, portanto, observou a presença de anticorpos anti-C. burnetii em pequenos ruminantes, confirmando pela primeira vez que este agente pode estar circulando em rebanhos caprinos no bioma Caatinga, semiárido do Brasil.

Palavras-chave: Febre Q, RIFI, pequenos ruminantes, zoonoses, Pernambuco.

\section{Introduction}

Coxiella burnetii, an obligate intracellular Gram-negative bacterium, is the causative agent of Q Fever. It was first classified in the order Rickettsiales, but was later reallocated to the order Legionellales

*Corresponding author: Maurício Claudio Horta. Laboratório de Doenças Parasitárias, Universidade Federal do Vale do São Francisco - UNIVASF, Rodovia BR-407, Km 12, Lote 543, s/n, Projeto de Irrigação Nilo Coelho, CEP 56300-000, Petrolina, PE, Brasil. e-mail: horta.mc@hotmail.com
(ANGELAKIS \& RAOULT, 2010). The primary reservoirs of C. burnetii are sheep, goats, and cattle. Usually asymptomatic, the infection may cause spontaneous abortion at the end of gestation, as well as other reproductive failures. It can be excreted into the environment through vaginal secretions, birth products, urine, feces, semen, and milk. The agent can survive in soil for long periods and be carried by the wind over distances of up to $30 \mathrm{~km}$ (ELDIN et al., 2017). 
In Brazil, the presence of $C$. burnetii in humans has been reported by serological and/or molecular assays in the states of São Paulo (BRANDÃO et al., 1953; VALLE et al., 1955; SICILIANO et al., 2015), Rio de Janeiro (LAMAS et al., 2009, 2013; LEMOS et al., 2011, 2018; ROZENTAL et al., 2012; MARES-GUIA et al., 2016), Minas Gerais (RIEMANN, et al., 1974; COSTA et al., 2005, 2006) and Bahia (SICILIANO et al., 2008). Among three Brazilian states (Rio de Janeiro, Piauí, and Alagoas), seropositive reactions to $C$. burnetii have been identified in dogs, sheep and/or goats, and/or C. burnetii DNA has been amplified from goat milk or placenta, or dog blood (MARES-GUIA et al., 2014; GUIMARÁES et al., 2017; OLIVEIRA et al. 2018). Therefore, this zoonotic disease was included in Brazil's list of notifiable diseases in 2013 (BRASIL, 2013).

In Northeastern Brazil, extensive farming is normally used to raise small ruminants to produce meat and milk for the farmer's own consumption or for sale. The economic importance of these animals in the region is significant, despite their low productive and reproductive performance, which causes financial losses to farmers (ALENCAR et al., 2010; PEREIRA et al., 2013). Given the importance of research into the epidemiological aspects that contribute to the introduction of pathogens into small ruminant farms, the aim of this study was to identify the main risk factors associated with the presence of anti- $C$. burnetii antibodies in goats and sheep in a semi-arid region of the state of Pernambuco, northeastern Brazil, where to our knowledge, there has been no investigation on $C$. burnetii.

\section{Material and Methods}

\section{Study area}

The municipality of Petrolina is located in the state Pernambuco (-9.39416 Latitude and -40.5096 Longitude), Brazil. Petrolina is within the Caatinga Biome, where the semi-arid climate is typically hot and dry, with an annual average temperature of $25.7^{\circ} \mathrm{C}$ (IBGE, 2015). Petrolina has an estimated ruminant population of 233,900 goats and 157,500 sheep, and the municipality covers an area of $4,561.874 \mathrm{~km}^{2}$. Random visits were made to 26 farms located in five areas: Sequeiro, Capim, Pontal, Irrigation Projects, and Riverside areas.

\section{Sampling procedures}

A total of 815 healthy small ruminants (412 goats and 403 sheep), 6 to 120 months old, of different breeds (although most were crossbreeds) were sampled between March and September 2016. This sample size was previously estimated based on an estimated $50 \%$ prevalence, $5 \%$ absolute precision, and $95 \%$ confidence interval (THRUSFIELD, 1995). Approximately 25 animals were conveniently selected for blood collection at each farm. A farm was deemed positive when it presented at least one seropositive animal.
Blood samples from small ruminants were collected by jugular venipuncture and were centrifuged (3,600 rpm, $10 \mathrm{~min})$, and the serum obtained from each animal was aliquoted into $1.5 \mathrm{ml}$ tubes and stored at $-20{ }^{\circ} \mathrm{C}$ until the time of examination. Geographic coordinates were obtained by GPS to create maps, using the ArcGis program, pinpointing the location of seropositive and seronegative animals.

The farmers were asked to fill out a comprehensive questionnaire about possible risk factors for $C$. burnetii. The information collected included the general characteristics of the farms: species (goat or sheep), breed (pure or mixed breed), age (0-1, 1-4 and > 4 years), breeding system (intensive or extensive), type of corrals (covered or open), reproductive disorders (occurrence of spontaneous abortion, malformed offspring), sanitary aspects (corral cleaning frequency, presence of ectoparasites, availability of veterinary care) and the location (Sequeiro, Capim, Pontal, Irrigation Projects, and Riverside areas).

This study was approved by the Committee on Ethics and Deontology in Studies and Surveys (CEDEP-Univasf) under Protocol no. 0016/170516.

\section{Detection of antibodies}

The presence of anti-C. burnetii IgG antibodies in the sera of goats and sheep was assessed by the Indirect Fluorescent Antibody Test (IFAT) using crude antigens of $C$. burnetii strain At12 (PACHECO et al., 2013). For this purpose, strain At12 was cultivated in Vero cells and harvested when near $100 \%$ of the cells were infected. The infected cells were centrifuged at $12,000 \mathrm{~g}$ for 10 minutes and the pellet was washed in $0.1 \mathrm{M}$ phosphate-buffered saline (PBS, pH 7.4), centrifuged again, and resuspended in PBS containing $0.1 \%$ sodium azide. Ten microliters of $C$. burnetii-infected cells were applied onto each well of 12 antigen slides. The antigens on the slides were air-dried and then fixed in acetone for 10 minutes. Slides were kept at $-20{ }^{\circ} \mathrm{C}$ until used.

Animal sera were diluted in two-fold increments with PBS starting from a 1:64 dilution. Ten microliters of diluted sera were added to each well of the antigen slides. The slides were incubated at $37^{\circ} \mathrm{C}$ for $30 \mathrm{~min}$ in a humid chamber. The slides were rinsed once, and then washed twice for $10 \mathrm{~min}$ per wash in PBS. The slides were incubated with fluorescein isothiocyanate-labeled rabbit anti-goat (dilution 1:1,000) and rabbit anti-sheep IgG (dilution 1:1,000) (Sigma, St Louis, USA), and washed as described earlier. The slides were mounted with buffered glycerin under coverslips. The slides were read using an ultraviolet microscope (Olympus, Tokyo, Japan) at 400x magnification. Samples were run in duplicates. Serum was considered to contain antibodies against $C$. burnetii if it reacted at a dilution of 1:64 (PACHECO et al., 2013), according to the protocol described by Reeves et al. (2006). Endpoint titers against C. burnetii were determined by testing two-fold serial dilutions of serum. Each slide contained a serum previously shown to be non-reactive (negative control) and a serum known to be reactive (positive control) (GUIMARÃES et al., 2017). 


\section{Risk factor analysis}

The variables were organized for presentation in ascending or descending order in terms of scale of risk. When necessary, these variables were recategorized. The lower-risk category was used as baseline for comparison with the other categories. An initial exploratory analysis of the data (univariable) was conducted to select variables with $\mathrm{P} \leq 0.2$ by the chi-square test or Fisher's exact test. The variables that passed this cut-off were then subjected to logistic regression (HOSMER \& LEMESHOW, 2000), and variables presenting $\mathrm{P}$-value $<0.05$ were considered risk factors. The fit of the final model was ascertained by means of the Hosmer and Lemeshow test, and collinearity between independent variables was determined by correlation analysis. For variables with a strong collinearity (correlation coefficient of $>0.9$ ), one of the two variables was excluded from the multiple analysis, according to their biological plausibility (DOHOO et al., 1997). Confounding was assessed by monitoring the changes in the model parameters when adding new variables. If substantial changes (i.e., higher than $20 \%$ ) were observed in the regression coefficients, this was considered as indicative of confounding. The calculations were performed using SPSS version 20.0 software.

\section{Results}

Anti-C. burnetii antibodies were detected in 2.2\% (18/815) of the small ruminants, $2.1 \%(9 / 412)$ of which were goats and $2.2 \%(9 / 403)$ were sheep. At least one seropositive animal was identified at eight (30.8\%) farms. Figure 1 presents the spatial location of positive and negative farms. Endpoint titers ranged from 64 to 4,096 for goats, and 64 to 65,536 for sheep (Table 1).

In the univariable analysis for $C$. burnetii in goats, the variables of breed, breeding system, type of installations, gestation phase abortion, disposal upon death, veterinary care, and location showed $\mathrm{P}<0.20$ and were significant and selected for the multivariate analysis, which indicated that intensive breeding was a risk factor (Table 2$)$. In sheep, the variables selected $(P<0.20)$ in the univariable analysis were sex, breed, age, type of installations, installation cleaning frequency, fecal fate, preterm birth, weak offspring, deworming, and location (Table 3). Multivariate analysis indicated that male animals, and location (Sequeiro) were risk factors (Table 4). Both final models (for goats and sheep) presented a good fit (Hosmer and Lemeshow test: $\mathrm{P}>0.05$ ).

Table 1. Endpoint antibody titers against Coxiella burnetii in goats and sheep, Petrolina municipality, Brazil.

\begin{tabular}{cccc}
\hline Titer & Goat (n) & Sheep (n) & Total \\
\hline 64 & 3 & 1 & 4 \\
128 & 1 & - & 1 \\
256 & - & 1 & 1 \\
512 & - & 3 & 3 \\
1,024 & 2 & 2 & 4 \\
2,048 & 1 & - & 1 \\
4,096 & 2 & - & 2 \\
32,768 & - & 1 & 1 \\
65,536 & - & 1 & 1 \\
\hline
\end{tabular}

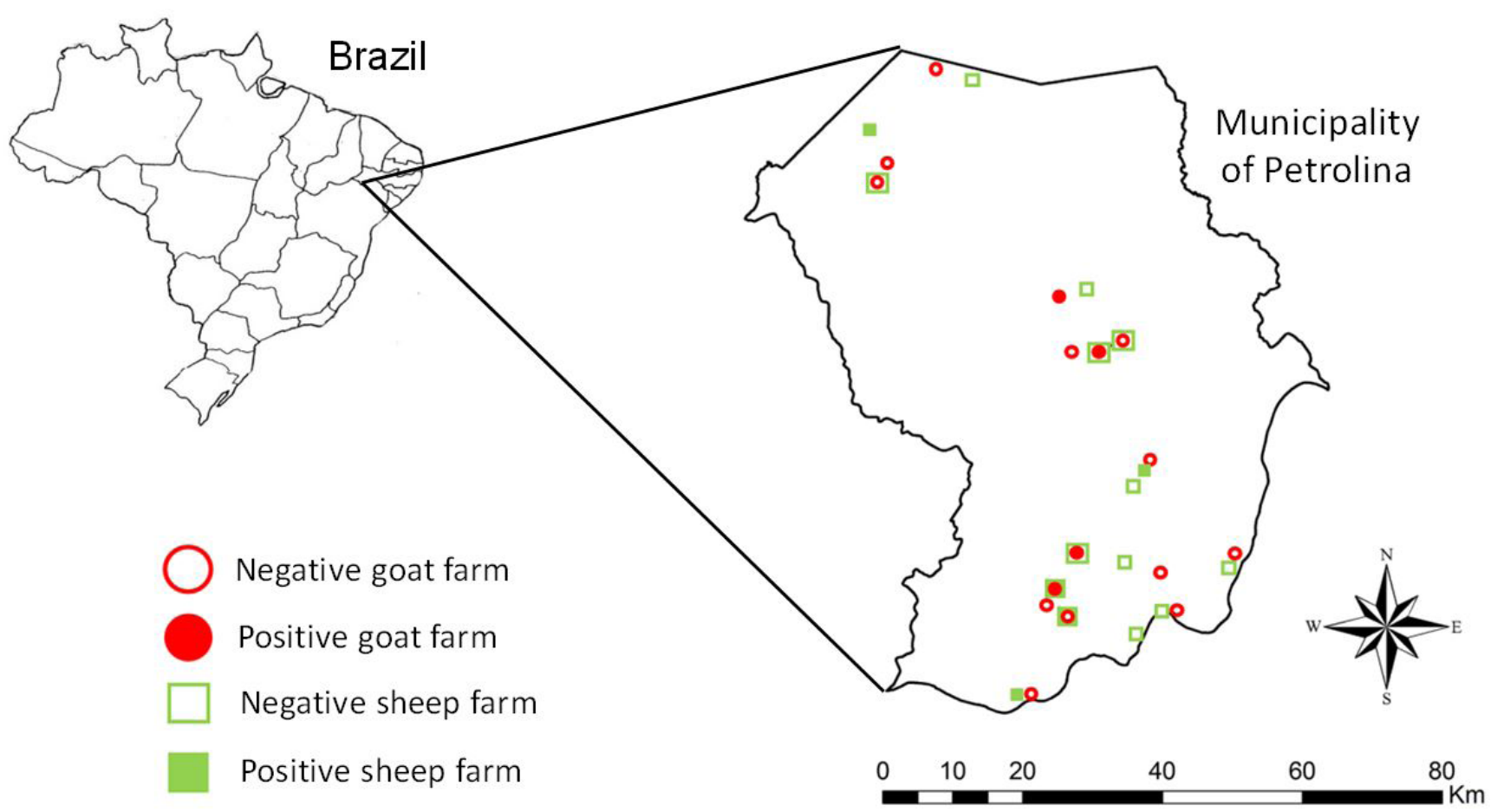

Figure 1. Map of Petrolina municipality of Pernambuco State, Brazil, indicating the location of 26 farms according to serological condition of animals. 
Table 2. Univariable analysis for risk factors showing the variables associated $(\mathrm{P}<0.20)$ with Coxiella burnetii seropositivity in goats from Petrolina municipality, State of Pernambuco, Brazil.

\begin{tabular}{|c|c|c|c|c|}
\hline Variable & Category & $\mathrm{N}^{\circ}$ total of animals & $\mathrm{N}^{\circ}$. of positive animals $(\%)$ & p-value \\
\hline \multirow[t]{2}{*}{ Breed } & Mixed breed & 361 & $2(0.6)$ & $<0.001$ \\
\hline & Pure & 41 & $7(17.1)$ & \\
\hline \multirow[t]{2}{*}{ Type of breeding } & Intensive & 25 & $5(20)$ & $<0.001$ \\
\hline & Extensive & 377 & $4(1.1)$ & \\
\hline \multirow[t]{2}{*}{ Type of corrals } & Covered & 25 & $5(20)$ & $<0.001$ \\
\hline & Descovered & 377 & $4(1.1)$ & \\
\hline \multirow{3}{*}{$\begin{array}{l}\text { Gestation season } \\
\text { abortion }^{\text {a }}\end{array}$} & Outset & 53 & $2(3.8)$ & 0.154 \\
\hline & Medium & 71 & $1(1.4)$ & \\
\hline & Finale & 100 & $0(0)$ & \\
\hline \multirow{2}{*}{$\begin{array}{l}\text { Animal destination in } \\
\text { death }^{\mathrm{b}}\end{array}$} & Discard/burn & 175 & $0(0)$ & 0.098 \\
\hline & Burn & 152 & $4(2.6)$ & \\
\hline \multirow[t]{2}{*}{ Veterinary assistance ${ }^{c}$} & No & 277 & $4(1.4)$ & 0.024 \\
\hline & Yes & 75 & $5(6.7)$ & \\
\hline \multirow[t]{2}{*}{ Area } & Sequeiro, Pontal, Capim, River & 281 & $3(1.1)$ & 0.024 \\
\hline & Irrigation projects & 121 & $6(5)$ & \\
\hline
\end{tabular}

${ }^{\mathrm{a}} \mathrm{n}=224 ;{ }^{\mathrm{b}} \mathrm{n}=327 ;{ }^{\mathrm{c}} \mathrm{n}=352$

Table 3. Univariable analysis for risk factors showing the variables associated $(\mathrm{P}<0.20)$ with Coxiella burnetii seropositivity in sheep from Petrolina municipality, State of Pernambuco, Brazil.

\begin{tabular}{|c|c|c|c|c|}
\hline Variable & Category & $\mathrm{N}^{\circ}$ total of animals & $\mathrm{N}^{\circ}$. of positive animals $(\%)$ & p-value \\
\hline \multirow[t]{2}{*}{ Sex } & Male & 75 & $5(6.7)$ & 0.022 \\
\hline & Female & 330 & $5(1.5)$ & \\
\hline \multirow[t]{2}{*}{ Breed } & Mixed breed & 361 & $7(1.9)$ & 0.083 \\
\hline & Pure & 44 & $3(6.8)$ & \\
\hline \multirow[t]{3}{*}{ Age (years-old) } & $0-1$ & 100 & $1(1)$ & $<0.001$ \\
\hline & $1-4$ & 291 & $5(1.7)$ & \\
\hline & $>4$ & 14 & $4(28.6)$ & \\
\hline \multirow[t]{2}{*}{ Type of corrals } & Covered & 373 & $8(2.1)$ & 0.183 \\
\hline & Descovered & 32 & $2(6.2)$ & \\
\hline \multirow[t]{4}{*}{ Frequency of installations cleaning ${ }^{a}$} & Fortnightly & 103 & $6(5.8)$ & 0.126 \\
\hline & Monthly & 47 & $1(2.1)$ & \\
\hline & Bimonthly & 79 & $1(1.3)$ & \\
\hline & Quarterly & 54 & $0(0)$ & \\
\hline \multirow[t]{3}{*}{ Fecal fate ${ }^{a}$} & Sells & 76 & $6(7.9)$ & 0.005 \\
\hline & Discard & 28 & $1(3.6)$ & \\
\hline & Reuses & 179 & $1(0.6)$ & \\
\hline \multirow[t]{2}{*}{ Preterm birth $^{a}$} & No & 156 & $7(4.5)$ & 0.078 \\
\hline & Yes & 127 & $1(0.8)$ & \\
\hline \multirow[t]{2}{*}{ Weak offspring ${ }^{\mathrm{a}}$} & No & 130 & $7(5.4)$ & 0.026 \\
\hline & Yes & 153 & $1(0.7)$ & \\
\hline \multirow[t]{2}{*}{ Deworming $^{a}$} & No & 1 & $1(100)$ & 0.028 \\
\hline & Yes & 282 & $7(2.5)$ & \\
\hline \multirow[t]{4}{*}{ Area } & Sequeiro & 78 & $5(6.4)$ & 0.071 \\
\hline & Pontal & 77 & $2(2.6)$ & \\
\hline & Capim & 40 & $1(2.5)$ & \\
\hline & Irrigation projects/River & 210 & $2(1)$ & \\
\hline
\end{tabular}


Table 4. Multivariable analysis (logistic regression) with the risk factors associated with Coxiella burnetii seropositivity in small ruminants from Petrolina municipality, State of Pernambuco, Brazil.

\begin{tabular}{lccccc}
\hline \multicolumn{1}{c}{ Risk fator } & Regression coeficiente & Standard error & Wald & Odds ratio (IC 95\%) & p-value \\
\hline Goat & & & & & \\
$\quad$ Intensive breeding & 3.168 & 1.123 & 7.960 & $23.7[2.6-214.5]$ & 0.005 \\
Sheep & & & & & \\
$\quad$ Male animals & 1.701 & 0.729 & 5.438 & $5.5[1.3-22.9]$ & 0.020 \\
Area - Sequeiro & 1.923 & 0.857 & 5.038 & $6.8[1.3-36.6]$ & 0.025 \\
\hline
\end{tabular}

\section{Discussion}

While we found a relatively low seroprevalence for $C$. burnetii $(<3.3 \%)$ among sheep and goat, it is noteworthy that half of the seropositive animals had high endpoint titers, varying from 1,024 to 65,536 (Table 1). High endpoint titers are suggestive of recent infection (GUIMARÁES et al., 2017; OLIVEIRA et al., 2018); however, we cannot discard cross-reactions with other unknown agents in some of our seropositive animals, especially those with low endpoint titers. Regardless, the overall low seroprevalence values in the present study are similar to the $2 \%$ (3/153) seroprevalence on sheep that was reported in another study from the Caatinga Biome (south of Piauí state) in northeastern Brazil (GUIMARÃES et al., 2017). In contrast, much higher seropositivity to $C$. burnetii has been reported among goats in the Agreste of the state of Alagoas (55.1\%; 172/312) (OLIVEIRA et al. 2018), and in the Atlantic forest Biome of Rio de Janeiro state, where $66.6 \%(2 / 3)$ of sheep and $50 \%(5 / 10)$ of goats were seropositive (MARES-GUIA et al., 2014).

The 26 farms of this study are located 3 to $50 \mathrm{~km}$ apart from each other. Although the occurrence of anti-C. burnetii antibodies was detected in only a few animals, the farms that had seropositive animals are distributed throughout the municipality (Figure 1). Since $C$. burnetii can disperse via aerosol over distances of up to $30 \mathrm{~km}$ (ELDIN et al., 2017), the agent is likely to be widely distributed in this study area.

Frequent cleaning of facilities prevents bacteria from accumulating inside corrals. In this study, the highest seropositivity was found on farms where facilities were cleaned out every fortnight to remove manure, which the farmers sold, reused or discarded in the environment. The problem with discarding untreated manure is that it contains the microorganism, i.e., after contaminated products of miscarriage and urine become aerosolized, they contaminate other environments and therefore other animals and humans. A comparative study found that C. burnetii was transmitted to humans more frequently when they were in the proximities of contaminated manure than in that of farms with Q fever (HERMANS et al., 2014).

In the present study, animals were divided by age into groups of 0-1 year (young), 1-4 years (adults), and > 4 years old. Older animals showed a higher percentage of seropositivity to $C$. burnetii, corroborating Anastácio et al. (2013) and Jung et al. (2014), who reported significantly higher seropositivity on older sheep and goat, when compared to young animals in the flock. This higher seroprevalence was expected, due the more probability of repeated contacts with the pathogen proportionally to life span (RIZZO et al., 2016).

An analysis of purebred, mixed and crossbred animals revealed a higher percentage of seropositivity among purebreds. In Indiana, USA, no significant difference in seropositivity was found between milk and meat goat breeds (BAUER et al., 2016). In Ontario, Canada, where intensive breeding is more common and the presence of the microorganism may be more prevalent, a higher prevalence of seropositivity was reported among milk goats (MEADOWS et al., 2015b). However, a study in Kenya carried out by Muema et al. (2017) found that animals raised in a pastoral nomadic system (similar to extensive farming) were three times more likely to test seropositive for C. burnetii than animals in other systems like mixed farming. This may be attributed to the wide-ranging mobility and contact between different pastoral herds during grazing and aggregation at common watering points; aggravated by the fact that $C$. burnetii persists and remains infectious in the environment for long periods.

In the present study, potential risk factors for $C$. burnetii infection were intensive farming for goats, and male sex and the Sequeiro location for sheep (Table 4). Extensive farming is a traditional livestock raising method in the region, which involves releasing animals into the native Caatinga (typical scrubland of the region) for the day and returning them to the corral at night. This method enables the animals to defecate, urinate or even abort during the daytime, leaving the products far removed from the homestead, thus minimizing the accumulation of the microorganism at the farm and thereby reducing the risk of infection among the animals. Intensive farming, which involves keeping animals permanently in the corral, is uncommon in this region. Such corrals usually have a roof and one solid wall to provide protection against strong winds. In this case, the microorganism remains in close contact with the animals for long periods of time. Thus, the proportion of seropositive animals is determined by the number of microorganisms distributed in the environment (MEADOWS et al., 2015a). Moreover, the risk of seropositivity is higher in poorly ventilated spaces (SCHIMMER et al., 2011). These facts lead us to assume that the low seropositivity found in this study may be associated with the extensive farming method practiced in the region.

Sequeiro is a region in the northern part of the municipality of Petrolina, where the farms most distant from the urban center are located. Although extensive farming predominates in this region, it was considered a risk factor here. The bacterium is not only resistant to high temperatures but can also survive in 
the environment for long periods (SESHADRI et al., 2003). The corrals on these farms are enclosed by fencing and have no roofs, facilitating the passage of the wind. Also, the animals graze through the Caatinga and are liable to come into contact with other animals, especially wildlife. This fact represents a research opportunity to gain a better understanding about the pathways of transmission in the region.

Male animals with good characteristics are usually selected for reproduction at the farms. These males are not allowed to roam freely in the pastures, either because of their aggressiveness or to prevent possible unintended mating with females in estrus, and also to ensure that they live longer. Therefore, they are more susceptible to disease and/or to possible reinfection. However, Meadows et al. (2015a) states that the probability of infection in females is higher due there are generally more female animals on a property than males.

This study revealed the prevalence of anti-C. burnetii antibodies in small ruminants, suggesting that the agent circulates among goat and sheep herds in a semi-arid region of northeastern Brazil, and the possibility that goats and sheep act as reservoirs for the agent in the region. This study can also be seen as a starting point for further research aimed at gaining more in-depth knowledge about epidemiological factors, as well as improving diagnostic techniques to confirm the presence of active C. burnetii infection in animals and humans, adopting preventive measures for the productive and reproductive improvement of the herd, and preventing environmental contamination by products of animal origin, and consequently, dissemination of the disease in the Caatinga Biome of Brazil.

\section{Acknowledgements}

This work was supported by the Brazilian funding agencies Coordenação de Aperfeiçoamento de Pessoal de Nível Superior (CAPES), and Fundação de Amparo à Ciência e Tecnologia do Estado de Pernambuco (FACEPE).

\section{References}

Alencar SPA, Mota RA, Coelho MCOC, Nascimento SA, Abreu SRO, Castro RS. Perfil sanitário dos rebanhos caprinos e ovinos no sertấo de Pernambuco. Cienc Anim Bras 2010; 11(1): 131-140. http://dx.doi. org/10.5216/cab.v11i1.4051.

Anastácio S, Tavares N, Carolino N, Sidi-Boumedine K, Silva GJ. Serological evidence of exposure to Coxiella burnetii in sheep and goats in central Portugal. Vet Microbiol2013; 167(3-4): 500-505. http://dx.doi. org/10.1016/j.vetmic.2013.08.004. PMid:24060100.

Angelakis E, Raoult D. Q fever. Vet Microbiol 2010; 140(3-4): 297-309. http://dx.doi.org/10.1016/j.vetmic.2009.07.016. PMid:19875249.

Bauer AE, Hubbard KRA, Johnson AJ, Messick JB, Weng HY, Pogranichniy RM. A cross sectional study evaluating the prevalence of Coxiella burnetii, potential risk factors for infection, and agreement between diagnostic methods in goats in Indiana. Prev Vet Med 2016; 126: 131-137. http:// dx.doi.org/10.1016/j.prevetmed.2016.01.026. PMid:26897246.
Brandão H, Vale LAR, Christovão DA. Investigações sobre a febre "Q" em São Paulo - I - Estudo sorológico em operários de um frigorífico. Arq Fac Hig S Pub Univ Sao Paulo 1953; 7(1): 127-134. http://dx.doi. org/10.11606/issn.2358-792X.v7i1p127-131.

Brasil. Ministério da Agricultura, Pecuária e Abastecimento - MAPA. Instruçáo Normativa n ${ }^{\circ} 50$ de 24 de setembro de 2013 [online]. Diário Oficial da República Federativa do Brasil, Brasília, 2013. [cited 2016 Dec 10]. Available from: http://www.agricultura.gov.br/assuntos/sanidadeanimal-e-vegetal/saude-animal/arquivos-das-publicacoes-de-saude-animal/ Listadedoencasanimaisdenotificacaoobrigatoria.pdf

Costa PSG, Brigatte ME, Greco DB. Antibodies to Rickettsia rickettsii, Rickettsia typhi, Coxiella burnetii, Bartonella henselae, Bartonella quintana, and Ehrlichia chaffeensis among healthy population in Minas Gerais, Brazil. Mem Inst Oswaldo Cruz 2005; 100(8): 853-859. http://dx.doi. org/10.1590/S0074-02762005000800006. PMid:16444416.

Costa PSG, Brigatte ME, Greco DB. Questing one brazilian query: reporting 16 cases of Q fever from Minas Gerais, Brazil. Rev Inst Med Trop São Paulo 2006; 48(1): 5-9. http://dx.doi.org/10.1590/S003646652006000100002. PMid:16547572.

Dohoo IR, Ducrot C, Fourichon C, Donald A, Hurnik D. An overview of techniques for dealing with large numbers of independent variables in epidemiologic studies. Prev Vet Med 1997; 29(3): 221-239. http://dx.doi. org/10.1016/S0167-5877(96)01074-4. PMid:9234406.

Eldin C, Mélenotte C, Mediannikov O, Ghigo E, Million M, Edouard S, et al. From Q Fever to Coxiella burnetii Infection: a Paradigm Change. Clin Microbiol Rev 2017; 30(1): 115-190. http://dx.doi.org/10.1128/ CMR.00045-16. PMid:27856520.

Guimarães MF, Araujo AC, Freire DP, Machado DMR, Martins NNVM, Moraes-Filho J, et al. Investigaçáo sorológica de Rickettsia rickettsii e Coxiella burnetii em caprinos e ovinos no entorno do Parque Nacional da Serra das Confusóes, Piauí. Pesq Vet Bras 2017; 37(6): 555-560. http:// dx.doi.org/10.1590/s0100-736x2017000600004.

Hermans T, Jeurissen L, Hackert V, Hoebe C. Land-Applied goat manure as a source of human Q-Fever in the Netherlands, 2006-2010. PLoS One 2014; 9(5): e96607. http://dx.doi.org/10.1371/journal.pone.0096607. PMid:24788538.

Hosmer DW, Lemeshow S. Applied Logistic Regression. Second Edition. New York: John Wiley \& Sons; 2000. http://dx.doi.org/10.1002/0471722146.

Instituto Brasileiro de Geografia e Estatística - IBGE. Panorama da Pecuária Nacional [online]. Brasília: IBGE; 2015 [cited 2017 Jan 25]. Available from: https://cidades.ibge.gov.br/xtras/temas.php?lang=\&codmun=26 1110\&idtema $=159$ \&search $=$ pernambuco $\% 7$ Cpetrolina $\% 7$ pecuaria

Jung BY, Seo MG, Lee SH, Byun JW, Oem JK, Kwak D. Molecular and serologic detection of Coxiella burnetii in native Korean goats (Capra hircus coreanae). Vet Microbiol 2014; 173(1-2): 152-155. http://dx.doi. org/10.1016/j.vetmic.2014.06.029. PMid:25061007.

Lamas CC, Rozental T, Bóia MN, Favacho AR, Kirsten AH, Silva AP, et al. Seroprevalence of Coxiella burnetii antibodies in human immunodeficiency virus-positive patients in Jacarepaguá, Rio de Janeiro, Brazil. Clin Microbiol Infect 2009;15(Suppl 2): 140-141. http://dx.doi. org/10.1111/j.1469-0691.2008.02144.x. PMid:19298403.

Lamas CC, Ramos RG, Lopes GQ, Santos MS, Golebiovski WF, Weksler C, et al. Bartonella and Coxiella infective endocarditis in Brazil: molecular evidence from excised valves from a cardiac surgery referral center in Rio de Janeiro, Brazil, 1998 to 2009. Int J Infect Dis 2013; 17(1): 65-66. http://dx.doi.org/10.1016/j.ijid.2012.10.009. PMid:23219032. 
Lemos ERS, Rozental T, Mares-Guia MAM, Almeida DNP, Moreira N, Silva RG, et al. Q Fever as a cause of fever of unknown origin and thrombocytosis: First Molecular evidence of Coxiella burnetii in Brazil. Vector Borne Zoonotic Dis 2011; 11(1): 85-87. http://dx.doi.org/10.1089/ vbz.2009.0261. PMid:20569012.

Lemos ERS, Rozental T, Siqueira BN, Júnior AAP, Joaquim TE, Silva RG, et al. Q Fever in military firefighters during cadet training in Brazil. Am J Trop Med Hyg 2018; 99(2): 303-305. http://dx.doi.org/10.4269/ ajtmh.17-0979. PMid:29943714.

Mares-Guia MAMM, Rozental T, Guterres A, Gomes R, Almeida DN, Moreira NS, et al. Molecular identification of the agent of Q fever - Coxiella burnetii - in domestic animals in State of Rio de Janeiro, Brazil. Rev Soc Bras Med Trop 2014; 47(2): 231-234. http://dx.doi.org/10.1590/00378682-0076-2013. PMid:24861300.

Mares-Guia MAMM, Rozental T, Guterres A, Ferreira MS, Botticini RG, Terra AKC, et al. Molecular identification of Q Fever in patients with a suspected diagnosis of Dengue in Brazil in 2013-2014. Am J Trop Med Hyg 2016; 94(5): 1090-1094. http://dx.doi.org/10.4269/ajtmh.15-0575. PMid:26928831.

Meadows S, Jones-Bitton A, McEwen S, Jansen J, Menzies P. Coxiella burnetii seropositivity and associated risk factors in sheep in Ontario, Canada. Prev Vet Med 2015a; 122(1-2): 129-134. http://dx.doi.org/10.1016/j. prevetmed.2015.07.007. PMid:26376066.

Meadows S, Jones-Bitton A, McEwen S, Jansen J, Menzies P. Coxiella burnetii seropositivity and associated risk factors in goats in Ontario, Canada. Prev Vet Med 2015b; 121(3-4): 199-205. http://dx.doi.org/10.1016/j. prevetmed.2015.06.014. PMid:26231909.

Muema J, Thumbi SM, Obonyo M, Wanyoike S, Nanyingi M, Osoro E, et al. Seroprevalence and factors associated with Coxiella burnetii infection in small ruminants in Baringo County, Kenya. Zoonoses Public Health 2017; 64(7): 31-43. http://dx.doi.org/10.1111/zph.12342. PMid:28117947.

Oliveira JMB, Rozental T, Lemos ERS, Forneas D, Ortega-Mora LM, Porto WJN, et al. Coxiella burnetii in dairy goats with a history of reproductive disorders in Brazil. Acta Trop 2018; 183: 19-22. http:// dx.doi.org/10.1016/j.actatropica.2018.04.010. PMid:29621535.

Pacheco RC, Echaide IE, Alves RN, Beletti ME, Nava S, Labruna MB. Coxiella burnetii in ticks, Argentina. Emerg Infect Dis 2013; 19(2): 344346. http://dx.doi.org/10.3201/eid1902.120362. PMid:23343647.

Pereira MF, Mota RA, Peixoto RM, Piatti RM. Estudo de casos de aborto em caprinos e ovinos no estado de Pernambuco, Brasil. Ciênc Vet Tróp 2013; 16: 18-30.
Reeves WK, Loftis AD, Sanders F, Spinks MD, Wills W, Denison AM, et al. Borrelia, Coxiella and Rickettsia in Carios capensis (Acari: Argasidae) from a brown pelican (Pelecanus occidentalis) rookery in South Carolina, USA. Exp Appl Acarol 2006; 39(3-4): 321-329. http://dx.doi.org/10.1007/ s10493-006-9012-7. PMid:16821092.

Riemann HP, Brant PC, Franti CE, Reis R, Buchanan AM, Stormont C, et al. Antibodies to Toxoplasma gondii and Coxiella burnetii among students and other personnel in veterinary colleges in California and Brazil. Am J Epidemiol 1974; 100(3): 197-208. http://dx.doi.org/10.1093/ oxfordjournals.aje.a112028. PMid:4606228.

Rizzo F, Vitale N, Ballardini M, Borromeo V, Luzzago C, Chiavacci L, et al. $\mathrm{Q}$ fever seroprevalence and risk factors in sheep and goats in northwest Italy. Prev Vet Med 2016; 130: 10-17. http://dx.doi.org/10.1016/j. prevetmed.2016.05.014. PMid:27435642.

Rozental T, Mascarenhas LF, Rozenbaum R, Gomes R, Mattos GS, Magno $\mathrm{CC}$, et al. Coxiella burnetii, the agent of $\mathrm{Q}$ fever in Brazil: its hidden role in seronegative arthritis and the importance of molecular diagnosis based on the repetitive element IS1111 associated with the transposase gene. Mem Inst Oswaldo Cruz 2012; 107(5): 695-697. http://dx.doi. org/10.1590/S0074-02762012000500021. PMid:22850965.

Schimmer B, Luttikholt S, Hautvast JL, Graat EA, Vellema P, Duynhoven YT. Seroprevalence and risk factors of $Q$ fever in goats on commercial dairy goat farms in the Netherlands, 2009-2010. BMC Vet Res 2011; 7(81): 1-14. http://dx.doi.org/10.1186/1746-6148-7-81. PMid:22208798.

Seshadri R, Paulsen IT, Eisen JA, Read TD, Nelson KE, Nelson WC, et al. Complete genome sequence of the Q-fever pathogen Coxiella burnetii. Proc Natl Acad Sci USA 2003; 100(9): 5455-5460. http://dx.doi.org/10.1073/ pnas.0931379100. PMid:12704232.

Siciliano RF, Castelli JB, Mansur AJ, Pereira dos Santos F, Colombo S, Nascimento EM, et al. Bartonella spp. and Coxiella burnetii associated with community-acquired, culture-negative endocarditis, Brazil. Emerg Infect Dis 2015; 21(8): 1429-1432. http://dx.doi.org/10.3201/eid2108.140343. PMid:26197233.

Siciliano RF, Ribeiro HB, Furtado RHM, Castelli JB, Sampaio RO, Santos FCP, et al. Endocardite por Coxiella burnetii (febre Q). Doença rara ou pouco diagnosticada? Relato de caso. Rev Soc Bras Med Trop 2008 41(4): 409-412. http://dx.doi.org/10.1590/S0037-86822008000400017. PMid:18853017.

Thrusfield M. Surveys. In: Thrusfield M. Veterinary Epidemiology. Third Edition. University of Edinburgh: Blackwell Science; 1995. p. 228-246.

Valle LAR, Brandão H, Christovão DA, D’Apice M. Investigaçóes sobre a febre Q em São Paulo - II - Estudo em tratadores de gado e em bovinos. Arq Fac Hig Saude Publica Univ Sao Paulo 1955; 9(1-2): 167-180. http:// dx.doi.org/10.11606/issn.2358-792X.v9i1-2p167-180. 